\title{
Sustainable development of organic agriculture: Strategies of Russia and its regions in context of the application of digital economy technologies
}

\author{
N. Yu. Nesterenko ${ }^{1}$, N. V. Pakhomova ${ }^{1}$, K. K. Richter ${ }^{1,2}$ \\ ${ }^{1}$ St Petersburg State University, \\ 7-9, Universitetskaya nab., St Petersburg, 199034, Russian Federation \\ 2 European University Viadrina, \\ 59, Große Scharrnstraße, Frankfurt (Oder), 15230, Germany
}

For citation: Nesterenko N.Yu., Pakhomova N.V., Richter K. K. (2020). Sustainable development of organic agriculture: Strategies of Russia and its regions in context of the application of digital economy technologies. St Petersburg University Journal of Economic Studies, vol.36, iss. 2, pp. 217-242. https://doi.org/10.21638/spbu05.2020.203

\begin{abstract}
This paper analyzes the potential of organic agriculture to meet effectively the increasing demand for high-quality food, to increase its export potential, and to solve the country's import substitution problems. The article also reveals the importance of digital economy technologies for increasing the sustainability of organic production. Among the most significant are cloud computing and large databases that contribute to the development of precision farming, continuous online monitoring of the quality of various stages in technological chains, automation and robotization, etc. Following recommendations of the "Organic Agriculture 3.0" conception, the authors examine the appropriate environmental, economic, social, and institutional factors to elaborate complex development strategies for agriculture in Russia and its regions. A special environmental index is proposed to determine environmentally friendly regions that are mostly suitable for organic production. The authors discuss an economic indicator to assess the potential of unused agricultural land for organic farming. The proportion of unemployed working-age population in rural areas serves as a social indicator for the study. By analyzing these selected indicators, four groups of Russian regions with different conditions for developing organic agriculture are identified. With respect to varying potentials of the regions and the external institutional context, the authors qualify different regional competitive strategies and corresponding product niches. The study also provides guidelines for Russian agrarian and environmental policy to support effective development of organic production.

Keywords: sustainable development, digital economy technologies, organic agriculture 3.0, export potential, supply and demand for organic food, regional priorities, local food supply chains.
\end{abstract}

\section{Introduction}

In Russia, in the search for new sources of sustainable economic growth and to increase the well-being of the population, while implementing import substitution and expansion of non-oil exports, increasing attention is paid to the potential of the agricultural sector. In 2018, Russia's agricultural exports grew by $19.4 \%$, reaching 25.8 bln doll. In 2024,

(c) Санкт-Петербургский государственный университет, 2020 
according to official plans, it should increase to 45 bln doll. [Pertseva, 2019]. At the same time, both experts and representatives of official circles often focus on the traditional segment of agrarian production, with its inherent product specialization and organizational forms and domination by large-scale agro-business [Danshin, 2018; Klimova, 2017].

When assessing the traditional approach, scholars first notice that the agrarian sector misses an orientation to innovative products, processes, and high added value. Second, this approach does not take into account possibilities from the $4^{\text {th }}$ industrial revolution and digitalization. Third, the ecological impact of the growth of traditional agricultural production on other sectors of the economy remains out of serious analysis [Aganbegyan, Porfiryev, 2015; Porfiryev, 2015]. Usually, productivity growth is reached by increasing the use of mineral fertilizers, agricultural pest control chemicals, and other methods of largescale industrial production. This increases pressure on the environment as well.

In this context, several authors pay attention to opportunities from organic agriculture for integrated solutions to these problems [Schulze et al., 2015; Altukhov, Nechaev, Porfiriev, 2013; Norse, 2012; Einfalt, Kazda, 2016; Nesterenko, Pakhomova, 2016]. In discussing their proposals, the term "organic agriculture" should be clarified. The International Federation of Organic Agriculture Movements (IFOAM) suggests the following definition: "The organic agriculture is a production system that sustains the health of soils, ecosystems and people. It relies on ecological processes, biodiversity and cycles adapted to local conditions, rather than the use of inputs with adverse effects and combines tradition, innovation and science to benefit the shared environment and promote fair relationships and a good of life for all the parties involved"1.

This integrated approach will promote achievement of environmental, economic, and socio-cultural goals. In the case of Russia, this means reorienting the country's agro-industrial complex to innovative products with high export potential and potentially steady global market demand. It also means that organic agriculture will help meet the demand of the Russian population for high-quality, ecologically clean food. Focusing on this agricultural model will also contribute to increasing the innovative potential of the country's economy. In this case we can talk about the use of the whole complex of innovations, including product technological, organizational, marketing, and social innovations. An example of technological innovation is resource-saving technologies that provide minimal and "zero" soil treatment (tillage). Digital technologies promise significant innovation potential for the sustainable development of organic agriculture. In this context cloud computing and large database technologies are among the most important contributors to the development of precision farming as a key component in the third wave of modern agricultural revolutions, which replaces the so-called green revolution ${ }^{2}$. In the same context the use of the industrial Internet and high-resolution satellite data allow organizing online monitoring of the quality of the interconnected technological chains of organic production. The use of digital technologies to organize organic farming also contributes

${ }^{1}$ IFOAM - Organics International. URL: https://www.ifoam.bio/en/organic-landmarks/definitionorganic-agriculture (accessed: 11.02.2020).

2 "Precision agriculture is understood as application of precise and correct amount of inputs like water, fertilizer, pesticides etc. at the correct time to the crop for increasing its productivity and maximizing its yields" (Wikipedia. The Free Encyclopedia. URL: https://en.wikipedia.org/wiki/Precision_agriculture (accessed: 30.01.2020)). 
to the transparency of business processes, which is especially important to maintain high product quality and consumer confidence in organic products.

The development of organic production and the increase in its export potential will also lead to a significant reduction of environmental stress and will also mitigate climate risks. Let us discuss some of these consequences in more detail, as they are often beyond the attention of economists.

In many countries, especially in recent years, agriculture has received considerable attention due to global interest in reducing environmental pollution and avoiding global climate change. This sector accounts for $24 \%$ of the total burden on the environment in the form of greenhouse gas (GHG) emissions. In 2017, in Russia, the share of agriculture was $5.9 \%$, not including servicing branches and excluding LULUCF (Land Use, Land-Use Change and Forestry). While in Russia this share is relatively small, and although atmospheric emissions of agriculture decreased by $54 \%$ in 2017 in comparison with 1990, this sector is still considered a source of some of the most dangerous GHGs ${ }^{3}$. These GHGs include methane $\left(\mathrm{CH}_{4}\right)$ and nitrous oxide $\left(\mathrm{N}_{2} \mathrm{O}\right)$, whose negative climatic effects are many times higher than those of carbon dioxide. Not only GHG emissions, but also the production of mineral fertilizers is understood to have a negative ecological impact.

Measures to increase agricultural productivity over the last few years reveal questions in need of environmental policymaking. The growth of production, the increase of mineral fertilizer production, and the extension of export potential have been accompanied by increasing pressure on ecosystems. In 2018, according to National Report about the cadastre anthropogenic emissions from sources and absorption by scavengers greenhouse gases not regulated by the Montreal Protocol, emissions from production of ammonia and nitric acid, mostly used for mineral fertilizer production, amounted for $50 \%$ of all GHG emissions in the chemical industry ${ }^{4}$. Nevertheless, agricultural productivity in Russia remains behind productivity of countries with comparable climatic conditions. For example, in 2017 in Russian yield of cereal was only $2.964 \mathrm{t} / \mathrm{ha}$, compared with $4.043 \mathrm{t} / \mathrm{ha}$ in Canada and $4.200 \mathrm{t} / \mathrm{ha}$ in Poland ${ }^{5}$. One of the main reasons for this lag is the limited use of mineral fertilizer. In 2016 Canadian consumption of fertilizer reached $87.6 \mathrm{~kg} / \mathrm{ha}$, versus $172.8 \mathrm{~kg} / \mathrm{ha}$ in Poland and only $18.5 \mathrm{~kg} / \mathrm{ha}$ in Russia $(2016)^{6}$. Overcoming this lag without appropriate environmental measures will be accompanied by an increase in the negative ecological consequences. One of such measures can be the development of organic agriculture, which is characterized by less negative environmental impact.

Raising the question of the accelerated development of organic agriculture, specialists also draw attention to Russia's avorable opportunities for increasing the supply of organic food to the national and international markets. Russia possesses potentially significant areas for developing organic agriculture. According to the Russian agricultural census of $2016,17628.8$ thousand ha of agricultural land were not used for their intended pur-

${ }^{3}$ United Nations Climate Change. URL: https://unfccc.int/documents?f\%5B0\%5D=document_ type\%3A4145 (accessed: 1.05.2020).

${ }^{4}$ United Nations Climate Change. URL: https://unfccc.int/documents?f\%5B0\%5D=document_ type\%3A4145 (accessed: 1.05.2020).

${ }^{5}$ The World Bank. Data.worldbank.org. URL: https://data.worldbank.org/indicator/AG.YLD.CREL. KG (accessed: 17.02.2020).

6 The World Bank. Data.worldbank.org. URL: https://data.worldbank.org/indicator/AG.CON.FERT. ZS (accessed: 15.02.2020). 
pose $-12 \%$ of all agricultural land in the country (142659.7 thousand ha $)^{7}$. An important prerequisite, as we shown in detail below, may be the presence in several regions of high unemployment, which might provide a pool of labor for organic production (after requisite training).

In general, experts regard the potential demand for organic food as favorable, especially in the global market. The production of organic products currently forms a dynamically developing segment of world agriculture, with an annual increase in production of $10 \%$ or more. Such dynamics are twice as high as the growth of the global food market. In 2017, the volume of production in this segment increased by $12 \%$, reaching $93 \mathrm{bln}$ euro. By 2020 , the global market for organic products is estimated to grow by $16 \%$ compared to the current year and its volume will be 143 bln euro $^{8}$. By 2025, the volume of consumption of organic products in the world will amount to 195.8 bln euro [Pertseva, 2019]. Compared to China, which is currently the world's leader in terms of organic arable land, Russia is geographically much closer to the largest market for organic products, European Union countries. The significance of this market is determined by the fact that the EU population is currently the global leader in consumption of organic food. In the EU, the share of organic products ranges from 0.2 to $9 \%$ of the total food supply. Of course, for the active participation of Russian producers in foreign markets, it is necessary to overcome considerable obstacles, including the mutual recognition of national certificates for organic products.

Currently, the demand for organic products in Russia is growing faster than globally, by $23 \%$ per year. However, the share of organic products in the country accounts for only $0.1 \%$ of the total food market, and on average only $1 \%$ of Russians buy organic fruits and vegetables [Prospects for the development..., 2019]. In absolute terms, the market volume is estimated at between $120 \mathrm{mln}$ euro and $160 \mathrm{mln}$ euro, while the share of domestic producers in this market is about $20 \%$. Less than $1 \%$ of all agricultural enterprises in Russia are engaged in producing organic products. And Russia's share in the global organic market is only $0.15 \%$. This situation is mainly a consequence of the fact that $95 \%$ of Russian investments in this sector are private. The state for all practical purposes does not participate in the development of this agricultural sector. Meanwhile, for organic production to become a stable segment of the national economy, it must occupy at least $10-15 \%$ of the country's food market [Maksimova, 2018]. These data indicate that there is significant potential for increasing the volume of organic production of both to increase the export of agriculture products and to meet the growing demand for high-quality food from the Russia population. They also indicate the need for a more active involvement in the development of this sector of all stakeholders, including the Russian government.

The problem of developing organic production of agricultural products has been discussed by experts for several years [Schulze et al., 2015; Altukhov, Nechaev, Porfiriev, 2013; Norse, 2012; Einfalt, Kazda, 2016; Nesterenko, Artemova, 2018; Pakhomova, Nesterenko, Richter, 2017]. Representatives of the authorities have also joined this discussion in recent years. Positive changes are also taking place in the preparation and adoption of legislation. 01.01.2020 the Federal Law "On Organic Products and on Amendments to Certain Leg-

\footnotetext{
7 The Russian Federal Department of Statistics.URL: http://www.gks.ru/news/perepis2006/totals-osn. htm (accessed: 11.01.2020).

${ }^{8}$ Rosbusinessconsulting.ru/ URL: https://www.rbc.ru/trends/green/5d656e9f9a79476e81356224 (accessed: 09.05.2020).
} 
islative Acts of the Russian Federation" entered into force, dated 03.08.2018 No.280-FL ${ }^{9}$. The legal basis for introducing organic principles in agricultural production is also formed by the following GOSTs of the Russian Federation: GOST R 56104-2014 "Organic food products. Terms and Definitions"; GOST R 57022-2016 “Organic Products. The order of the voluntary certification of organic production". In addition, the International Standard adopted by the Eurasian Council for Standardization, Metrology and Certification (EACS) is applied in the Russian Federation - GOST 33980-2016 "Organic Products. Rules of production, processing, labeling and implementation. NEQ CAC/GL32-1999". The International Standard of Eurasian Economic Union (EAEU) is harmonized with the EU Council Regulation No. 834/2007 of June 28, 2007 "On Organic Production and Labeling of Organic Products", as well as with the IFOAM basic standards. These standards form the regulatory basis for the production, identification and certification of organic products [Chukhlantsev, 2019]. At the same time, purposeful efforts are now needed to ensure international recognition of the standards adopted in Russia and in the EAEU.

Several important initiatives, including in connection with the preparation and adoption of Federal Law No. 280-FL, are being implemented at the level of the President of the Russian Federation and the Government of the Russian Federation. Thus, during the preparation of the Message to the Federal Assembly, the President, Vladimir Putin, instructed the preparation of measures necessary for the speedy creation and promotion of the Russian brand of environmentally friendly (organic) products to foreign markets. These measures are important for strengthening the export potential of Russian organic products. In the meantime, the country's organic brand is only being formed, and Russian exports not finished products, but mostly raw materials estimated at 10-12 mln euro per year [Labykin, 2019].

Along with the obstacles listed above, considerable restrictions in Russia also remain on the side of market demand, due to insufficient income of the main part of the population for consuming organic products. The price is usually higher for organic than traditional foods in developed countries by $30-50 \%$, while in Russia the price gap is $200-300 \%$. In this case, balancing supply and demand is most acute in the regional context because the supply of organic food comes mainly from regions with the most favorable conditions and resource potential for production, while demand for more expensive products is mainly concentrated in large cities. Until recently, it was presented mainly in the network retail premium segment [Nesterenko, Pakhomova, 2016; Nesterenko, Shagalkina, 2019; Arkhipova Kulagina, 2018].

Based on projects reported on this issue, published results, and unresolved problems, this paper will focus on development strategies for organic agriculture in Russia and in its regions, keeping in mind opportunities from digital technologies. The authors proceed from the fact that when determining strategic priorities for the development of organic farming, we should take into account the diversity of natural and climatic conditions, as well as discrepancies in the population's living standards in Russian regions. Regional differences in quality and areas of agricultural land, as well as availability of other resources, do not allow unified approaches and tools for developing this sector. Under these circumstances, it is more beneficial to concentrate on regional priorities and available production

${ }^{9}$ Consultant Plus. URL: http://www.consultant.ru/document/cons_doc_LAW_304017/ (accessed: 19.02.2020). 
and social resources [Shcherbakova, 2017; Avilova, 2016; Grigorian, Kulagina, Sungatullina, 2016; Nesterenko, Pakhomova, 2016].

The emphasis on regions can be justified by another circumstance. In conditions of permanent delays in the adoption of federal legislation, Russian regions were forced to develop and implement appropriate measures on their own initiative. Examples include regional laws on organic farming developed in 2013-2014 in Ulyanovsk and Voronezh Regions, in Krasnodar Territory, and several others. Regional experiences in the development of organic agriculture is of interest and can serve as a basis for developing differentiated strategies in the regions. However, these regional laws and experiences were not based on an analysis of regional production and natural resources within the context of a strategy for sustainable development of agriculture in Russia as a whole.

For determining such a strategy for sustainable development of organic agriculture, identifying the main areas for the application of digital technologies is often recommended [Knoll, Czymmek, 2018]. We rely on in their study. Some publications examine the application of digital technology in agriculture in general [Skvortsov et al., 2018].

Our article will explore prospects for developing organic agriculture in Russia, with an emphasis on differentiated regional strategies. The main objectives of this paper are:

- to complete an analysis on ways to reduce environmental impacts of agricultural production and on prerequisites that Russia has for developing organic agriculture;

- to identify strategic priorities for developing organic agriculture in Russia, by considering contemporary approaches to sustainable agriculture and with an emphasis on the regional dimension;

- to set up areas of application of digital economy technologies and their opportunities for overcoming barriers to developing organic agriculture;

- to reveal regions that have environmental, social, and economic potential for a transition to a model of organic agriculture and to qualify different regional competitive strategies and corresponding product niches for organic agriculture development;

- to propose some recommendations for the modernization of Russian agrarian and environmental policy.

\section{The environmental impact of Russian agriculture and preconditions for developing organic farming}

As noted earlier, the environmental impact of Russian agriculture could be improved further by the implementation of the Governmental Program on the development of agriculture for 2013-2020, which implies an increase in agricultural production by more than $24 \%$. However, this program doesn't include directions stipulating the reduction of environmental impacts of increasing agricultural production. The development of the economy, including growth in agricultural production, can lead to a considerable rise in greenhouse gas emissions by 2020. For example, over the past ten years, cereals production in Russia has been growing at an average annual rate of more than $10 \%$ per year. In 2017 cereal production reached $131.143 \mathrm{mln} \mathrm{t}^{10}$, of which $36.19 \mathrm{mln} \mathrm{t}$ were

10 The World Bank. Data.worldbank.org. URL: https://data.worldbank.org/indicator/AG.PRD.CREL. MT (accessed: 17.02.2020). 
exported ${ }^{11}$. Grain exports are intended to compensate for the deficit in the federal budget caused by a decrease in export revenues from the sale of hydrocarbons.

Assessing the ecological load of agriculture in Russia and its dynamics, it should be noted that the increase in energy efficiency of agriculture in an important trend in this sector. Certain efforts to raise energy efficiency in agricultural production are being taken, especially for animal husbandry. The decline in energy intensity in this sector, and hence the reduction of GHG emissions, are linked to the transition of several technological processes to the use of energy resources produced by processing agricultural waste. For example, Belgorod Region possesses stations to produce biofuels from livestock waste, which simultaneously solves the problem of waste disposal of the largest livestock complexes.

We have already noted significant opportunities in the field of organic farming development; it is possible to talk about $17.6 \mathrm{mln}$ ha suitable for organic farming. The objective of escalating agricultural production, specified by the Russian Government, focuses on the need for reclaiming this unutilized land. As a result, considerable investment in soil purification will accompany both organic agriculture and industrial production of agricultural products. Forest areas are also a potential reserve to develop organic production. In 2015 up to $8.3 \%$ of all organic products in Russia were wild plants. In prospect, this niche can be developed by involving the population of rural areas and certification of these areas.

At the same time, experts rightly warn that advantages of developing organic agriculture should be promptly realized. So far, not only the volume of organic food production is extremely small in the country, but due to an underdeveloped certification system, products already produced cannot be recognized as organic either in the domestic or, especially, international markets. Several large foreign producers operating in Russia and intending to launch organic product lines, such as Danone, faced a shortage of raw materials. The situation is similar with network retail, which today is ready to allocate shelf space for organic products and to conduct independent PR campaigns. Entering international markets requires intensifying efforts to recognize Russian standards for organic products by IFOAM, whose standards are the basis for national standards in all countries [Labykin, 2019].

The success of developing organic production, experts note, is to a large extent related to the speed of measures being implemented, until the global market is saturated and organic products bring increased margins. Today, it is necessary to increase attention to producing organic food at all levels: both from the executive and legislative branches of power in the center and in the localities, and from agricultural producers. Among the most important goals today is developing strategies at the federal and regional levels for developing organic agriculture, justifying their priority areas, determining the amount and sources of funding, information, and consulting support measures, and so on.

Prerequisites for developing organic agriculture, as well as the role of this model of agricultural production in reducing the environmental burden, will be in the focus of the authors and further, including when detailing the strategy for the development of organic production in a regional context.

11 The Statistics Portal for Market Data, Market Research and Market Studies. URL: https://www. statista.com/statistics/244263/exports-of-cereals-by-russia-2002-2013/ (accessed: 22.02.2020). 


\section{Research methodology and strategic priorities for developing organic agriculture in Russia}

Solving the tasks facing Russia to ensure the dynamic and effective development of organic agricultural production requires a well-thought-out methodology. This is the subject of discussion in scholarly literature. Some authors focus on problems of low-carbon agriculture [Smith et al., 2007; Davidson, 2009; Long, Lee, Tebeest, 2011; Norse, 2012; De Moraes et al., 2017]. They consider organic agriculture a key direction for the transition to a low-carbon economy in the agricultural sector. According to [De Moraes et al., 2017], low-carbon agriculture is based on three principles: low carbon dioxide $\left(\mathrm{CO}_{2}\right)$ emissions from land use changes and best practices; high $\mathrm{CO}_{2}$ mitigation through agricultural production systems based on best management practices; and high carbon sequestration potential with the adoption of integrated crop-livestock-forestry-systems.

This approach, with environmental goals as the highest priority and with viable means to achieve them, still seems too narrow. The concept of organic production 3.0 is more in line with modern integrated concepts of agricultural development. This concept was proposed by Strotdrees, which launched the idea of organic production 3.0 in 2011 [Strotdrees et al., 2011]. Arbenz defined Organic 3.0 as a modern, innovative agricultural system that holistically integrates ecology, economy, society, culture, and accountability into local and regional contexts [Arbenz, Gould, Stopes, 2017]. Altieri believed Organic 3.0 could have help solve tasks of climate change mitigation [Altieri et al., 2015]. The most important challenge for organic agriculture is to move from a purely agricultural perspective towards organic production as an agri-food system. Among the characteristics of this system are the following [Rahmann et al., 2017]:

1) production of healthy and safe food in volumes that can meet the needs of the growing population;

2) reduction of pollution and greenhouse gas emissions derived from food production, processing, trading, and consumption;

3) development of food chains driven by renewable energy and recycled nutrients;

4) adoption to climate change and mitigating greenhouse gas emissions;

5) protection of soils, water, air, biodiversity, and landscapes;

6) incorporation of current and emerging ethical systems, food habits, lifestyles and consumer needs.

It follows from these characteristics that Organic 3.0 includes the culture of innovation; continuous improvement towards best practices; diverse ways to ensure transparency and integrity; inclusive of wider sustainability interests; empowerment from the farm to the final customer; and true value and cost accounting.

The concept of organic production 3.0 needs some modernization in the context of the digital revolution. Several authors, studying the impact of the $4^{\text {th }}$ industrial revolution and related digital technologies on organic agriculture, have developed the concept of organic production 4.0. This concept deserves serious attention and will serve as the methodological basis for our subsequent analysis. F. J. Knoll and V.Czymmek, in this regard, note that "digitization makes it possible to collect, store, analyze, and communicate large amounts of data. By digitizing farms, a network of different sensors can analyze the nutrient content and the soil texture in real time. This information can be evaluated, and the plant distribution can be managed across all networked farms. This leads to the right field 
being used for the right plant at the right time" [Knoll, Czymmek, 2018, p. 17]. The use of digital technologies is not only the basis of the precision farming model, but also, as was noted earlier, contributes to the transparency of business processes, which is especially important to maintain high product quality and consumer confidence in organic products. In the following analysis, we will explore possible applications of digital technologies in organic production.

However, let us return to Organic 3.0. Among the characteristics noted earlier and tasks solved by Organic 3.0, it is important to focus on economic, social, and environmental objectives. It is easy to see that these goals are central to the contemporary concept of sustainable development.

Let us begin with the social dimension of sustainable development and organic agriculture. Agriculture, being the fundamental activity of humankind, is traditionally considered an economic activity with important social functions. It provides a significant part of the global population with jobs and income. The social dimension must also be considered when assessing economic efficiency of production and consumption of organic food, including the positive effects of environmentally friendly products on the health of the population, especially children. Furthermore, forcing the development of this sector can have a positive impact on the social situation in rural areas by involving local people in production processes and preserving a traditional way of life [Schulze et al., 2015; Nesterenko, Pakhomova, 2016].

At the same time, the social effects of organic production are not unambiguous. The industrial model of agrarian production provides significant improvement in working conditions and standards of well-being for rural workers in general. We cannot ignore numerous examples of violations of minimum wage laws by eco-farmers to ensure their price competitiveness with conventional farms ${ }^{12}$. In this regard, it is worth paying attention to computerization and robotization, which have significant potential for reducing the need for workers, including those engaged in manual operations. Robotization of agriculture animal husbandry is currently gaining ground in domestic enterprises that use the organic production model and it can bring tangible effects through monitoring animal health, controlling the quality of milk, rational use of feed, etc. Computerization and robotization not only reduce costs and increase efficiency of animal husbandry, but also can help solve reduce shortages of skilled labor in rural areas [Skvortsov et al., 2018].

Comparison of the conventional and the organic agricultural models must consider the goal of increasing food production for growing populations and to raise living standards. In this context specialists pay attention to the higher economic efficiency of conventional agricultural production, including its higher productivity [Schulze et al., 2015; Schulz, 2012]. In Russia, agriculture faces challenges of growth in domestic demand for food as well. Moreover, as noted, Russian agriculture must increase its export potential by almost $80 \%$ to cover budget revenues lost by declining raw material exports. In addition, the industrial model is characterized by moderate consumption of energy resources in comparison with organic production, if we consider the lower productivity and yield of the latter ${ }^{13}$.

12 Zeit ONLINE. URL: http://www.zeit.de/2016/13/landwirtschaft-oekobauer-mitarbeiter-ausbeute (accessed: 22.03.2020).

${ }^{13}$ ATTRA Sustainable Agriculture. URL: https://attra.ncat.org/attra-pub/summaries/summary. php?pub=301 (accessed: 17.03.2020). 
At the same time, a comparison of economic efficiency of traditional and organic farming models is incomplete without considering opportunities available from precision farming methods. According to some estimates, the Green Revolution, with new methods of genetic modification, increased labor productivity and allowed each farmer to feed about 155 people. By 2050, the global population will reach about $9.6 \mathrm{bln}$, and food production must effectively double from current levels. With new technological advancements in the agricultural revolution of precision farming, each farmer will be able to feed 265 people on the same acreage ${ }^{14}$.

As for the ecological dimension, despite earlier beliefs, many studies have shown that organic agriculture does not have absolute environmental benefits [Schulze et al., 2015; Williams, Audsley, Sandars, 2006; Schulze, 2014]. For example, in the case of grazing cattle as required by organic agriculture, greenhouse gas emissions are higher than for stabling. Thus, ecological aspects of the problem require in-depth study. On the one hand, agriculture is one sector most vulnerable to adverse climate impact. Experts estimate that global food production could drop by $17 \%$ for each degree of temperature rise because of extreme weather events (drought, flooding, etc.) ${ }^{15}$. On the other hand, agriculture must reduce its burden on the environment in terms of greenhouse gas emissions as per decisions taken at the Paris conference. According to The Fourth Biennium Report of the Russian Federation, a share of GHG emissions from agriculture is 5,9\% (Figure 1). Simultaneously, this sector has a significant potential for reducing GHG emissions, for example, due to the use of precision farming, organic technologies, and so on. These conclusions are correct for Russia's agriculture as well.

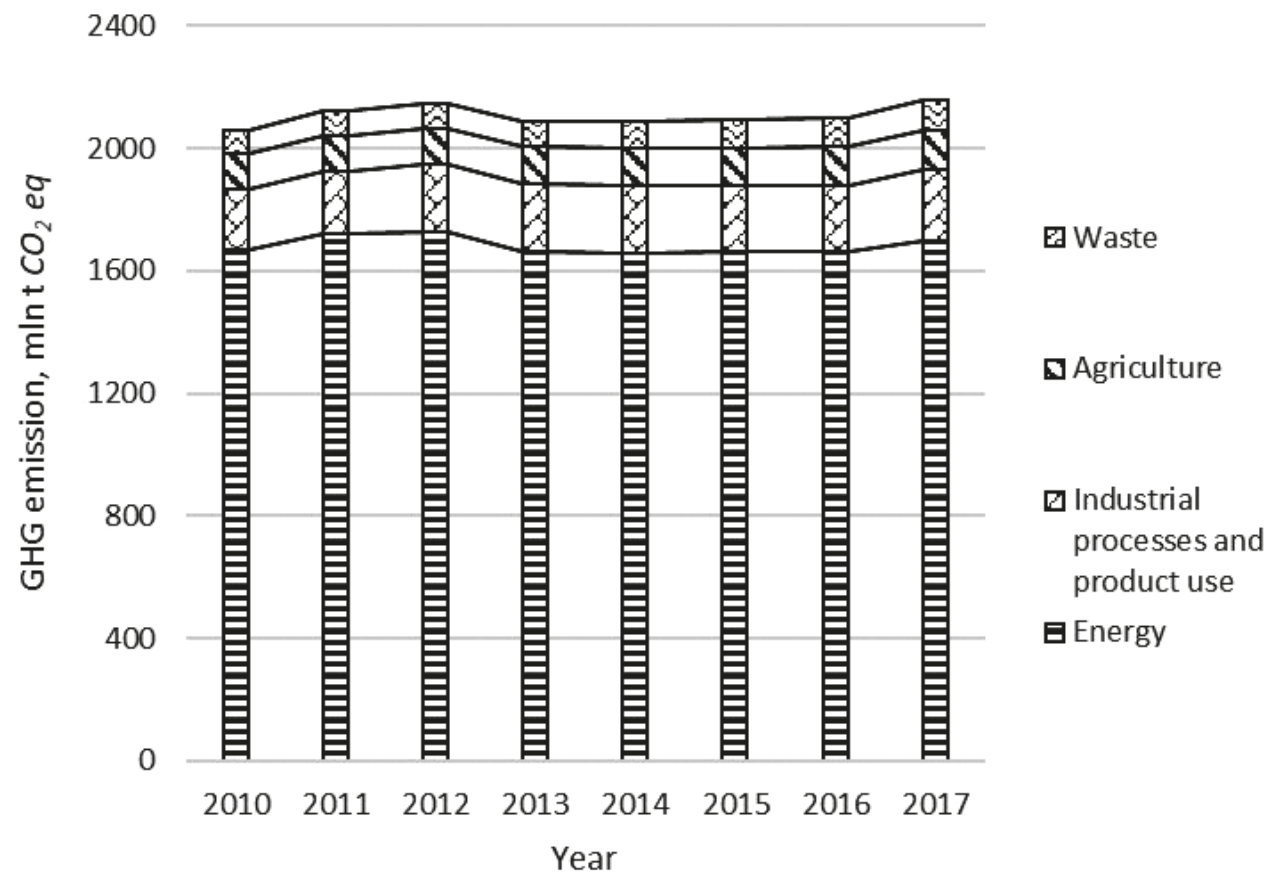

Fig. 1. GHG emission structure in Russia

B ased on: United Nations Climate Change. URL: https://unfccc.int/documents? f\%5B0\%5D=document_type\%3A4145 (accessed: 01.05.2020).

${ }^{14}$ Ernst \& Young Global.URL: https://www.ey.com/en_gl/advisory/how-digital-agriculture-and-bigdata-will-help-to-feed-a-growing-world (accessed: 14.01.2020).

${ }^{15}$ Agricultural and Rural Convention. URL: http://www.arc2020.eu/2015/12/what-will-the-parisagreement-mean-or-farming-food/ (accessed: 19.01.2020). 
These mixed results allow us to conclude that it is beneficial to apply different models to agricultural development and to elaborate balanced strategies for Russia and its regions. This can be achieved addressing to the contemporary conception of sustainable development, including "European Initiative for Sustainable Development in Agriculture" with its goal of merging advantages of traditional industrial methods with requirements of organic agriculture. The concept of integrated farming, developed within the framework of this initiative, is directly oriented to tasks facing agricultural enterprises. This concept, while supplementing capabilities inherent in digital technologies, may be useful for Russian agricultural businesses. By this concept, integrating farming is a sustainable production system that allows farmers to optimize farm management, to raise further awareness, and continually to improve everyday practice to meet future environmental, economic, and social challenges and hence achieve parallel progress in all dimensions of sustainable development ${ }^{16}$.

If summarized, "The European Initiative for Sustainable Development in Agriculture" demonstrates a holistic view of economic, ecological, and social challenges to society and a balanced way of development goals and strategies at the international, national, regional, and micro (business) levels. Based on this concept, it is possible to show that conventional agriculture has no negligible advantages compared to ecological agriculture, especially if the attention is drawn to the above-mentioned global task to supply the increasing world population with food and to provide for these people proper job quality and living conditions.

The development of a balanced and differentiated approach to agricultural production can also be observed when addressing the question of its place and role in softening global climate problems. In modern conditions agriculture needs to increase the volume of an agri-food production while managing climate change. In this context, attention should be paid to climate-optimized sustainable development of the industry. The main objectives of this concept are: steady increase in a productivity and a profitability of agriculture; adaptation and increased resilience to the climate change; and reduction and/or termination of greenhouse gas emissions where possible. Climate-optimized sustainable development is one of eleven corporate priority areas for resource mobilization within the framework of FAO's strategic objectives. It is consistent with the concept of sustainable nutrition and FAO's agriculture. And it supports FAO's goal to make agriculture and forestry, as well as fishing, more productive and sustainable ${ }^{17}$.

As for Russia, the growth of agricultural production leads not only to higher greenhouse gas emissions, but also to a significant environmental burden in terms of soil quality, biodiversity, and other aspects. However, developing sustainable agriculture is more multilateral and includes a social dimension. It is not reasonable to ignore that in rural areas there are many social problems including unemployment, low level of education, and lack of young people. The long-term crisis in this sector in Russia has led to many young people migrating to the cities.

The formation of adequate institutional conditions for developing agriculture, primarily its organic model, is one strategic task. The Federal Law "On Organic Products and Amendments to Certain Legislative Acts of the Russian Federation", adopted

\footnotetext{
${ }^{16}$ European Initiative for Sustainable Development in Agriculture. URL: http://sustainable-agriculture. org/integrated-farming/ (accessed: 10.02.2020).

17 AgroPraktik. URL: http://agropraktik.ru/blog/1005.html (accessed: 19.02.2020).
} 
on 03.08.2018 and coming into force on 01.01.2020, No. 280-FL, requires a system of regulatory documents ensuring its practical implementation. Russia's national standard of organic agriculture (GOST R 56508-2015) approved by in June 2015, needs international acceptance, especially from the European Union. Under these circumstances, best international practices need to be applied along with the EU experience to coordinate agricultural and environmental policy, which is currently being adapted to targets of the Paris agreements. These documents include the Action Plan for the future of Organic Production in the European Union (European Commission Brussels, 24.03.2014. COM (2014) 179 final), which also contributes to objectives set out in the Europe 2030 Strategy. In line with this document, the Common Agricultural Policy and the $7^{\text {th }}$ Environment Action Program 2020 require attention. Note that in Russia there are no analogues to several of the above-mentioned documents, making it difficult to conduct an effective public agricultural policy based on the principles of sustainable development. However, the government draft plan of measures for ratifying the Paris Agreement and its implementation is now being developed, which we consider a positive signal. The Russian Ministry of Agriculture also takes part in elaborating the Action plan to reduce greenhouse gas emissions.

Sustainable development of agriculture involves achieving a balance between supply and demand for agricultural products, as briefly noted - especially for organic production. Regarding the magnitude and structure of effective demand for organic products, several articles have focused on obtaining more accurate estimates of these parameters. They analyze such problems as willingness to pay the extra price for organic food, differences in the perception of local and foreign organic products, trust as a factor of choice, and the like. The organic food consumer's focus on local products is related not only with trust in local production processes, but also a willingness to support local producers. In Russia's case, this thesis is confirmed by [Shcherbakova, 2017] using the case of the Komi Republic. Consumers are more likely to buy organic products because of trust in production processes, including those in terms of environmental quality in a region. The consumer's willingness to pay a premium for organic products was researched in surveys conducted in Russian regions [Honkanen, Frewer 2009; Popova et al. 2010; Kravchenko, Stetsyuk, Kuripko, 2019; Scherbakova, 2017; Komarova, Beresneva, 2019]. Data indicate a willingness to purchase more expensive environmentally friendly products. However, it is worth noting that this is a characteristic of consumers with high earnings. For consumers with an average or below-average incomes, growth in demand for organic products will rely on more active social policy. Among priority measures in this area is reducing sharp differentiation in incomes (we recall that the Gini coefficient for incomes is about 14 in Russia), as well as pension reform.

Analyzing the task of balancing supply and demand for organic products, one should also turn to new opportunities from the active development of digital platforms in the economy, including in its agricultural segment. Digital platforms can perform various functions facilitating market transactions between different business entities [Richter, Pakhomova, 2018]. They facilitate the promotion of organic food by organizing networking between producers and consumers, reducing the number of intermediaries due to the spread of direct sales from the manufacturer. Digital platforms can combine manufacturers from different regions with minimal transaction costs, which is important for organic products, the production of which is often localized in some regions, and demand can be formed in completely different ones. It is necessary to pay attention to the fact that these 
opportunities are realized in practice. So, since 2016, the largest Russian digital platform PROD. CENTER has been functioning, which is focused on producers and buyers of agricultural products. Based on this platform, various products of livestock breeding and crop production, as well as poultry, fish, vegetables, and fruits, are traded. Another example is the Foofza digital logistics platform, which brings together more than 100 small and medium-sized farmers and greenhouse complexes throughout Russia, making it possible to directly connect manufacturers with wholesale buyers: restaurants, cafes, hotels, small shops. All these circumstances are important to keep in mind when analyzing the sustainable development of organic agriculture in a regional context.

\section{Selection of regions corresponding to environmental, social, and economic parameters for the transition to the model of organic agriculture}

Russia is characterized by a great diversity of geographic and cultural landscapes, which creates many opportunities and risks for sustainable development of agriculture. The geographic location of Russian regions and diversity of landscapes and climatic conditions require the development of differentiated strategies. To differentiate the regions while choosing priority organic clusters, we distinguish the following consumer parameters: the quality of the environment in a region, availability of unutilized agricultural land, and availability of labor force. Geographical proximity to large cities with high living standards is relevant only for those segments of organic agriculture in which perishable products are produced.

The main goal of this section of our study is to identify promising regions for developing organic agriculture, which not only possess the production resources of the required quality, but also where the level of environmental pollution is relatively low. We have analyzed the transition to organic agriculture by implementing internationally known methods for various Russian regions. Below we briefly describe this method. The authors identified factors contributing to the development of organic agriculture and regions that have the greatest potential for this task. Differentiation of the development of organic farming should be based on existing opportunities and barriers related to the environmental situation in the regions, the availability of production resources, and the possibilities of its support from the regional authorities.

As for production, the drivers of transition to organic farming are the availability of unutilized agricultural land and the number of unemployed people in rural regions. In addition, it is necessary to consider the impact of an environmental situation in the regions on the quality of organic products. To assess the quality of the environment in the regions, we also used data from an integrated environmental index calculated by the Russian non-governmental organization "Green Patrol"18. This index is formed by integrating the parameters that characterize the level of atmospheric pollution, the level of water pollution, the degree of soil degradation, protected natural territories, biodiversity, and climate changes.

${ }^{18}$ Green Patrol. URL: http://greenpatrol.ru/ru/stranica-dlya-obshchego-reytinga/ekologicheskiyreyting-subektov-rf?tid=310\&order=field_nature\&sort=asc (accessed: 09.01.2020). 
In the first stage of our research, we assess the ecological situation in Russia's regions and select regions where the quality of the environment corresponds to or exceeds the average level in Russia using data from NGO "Green patrol". The ecological rating of Russian regions is carried out because of generalization of information from various sources, including social media, authorities, public and expert organizations, economic entities and initiative groups of citizens. The scores obtained by rating are relative, and they depend on the indicators reached by all rating participants in the reporting period. Thus, the positions of a specific region in the index may differ from period to period with constant indicators due to changes in the indicators of other regions. Below we consider the indicators used in rating in detail:

- atmosphere - an indicator that reflects the level of air pollution in the Russian regions (more precisely, in subjects of the Russian Federation); this indicator also considers emergencies associated with pollutant emissions, modernization of gas treatment facilities, etc.;

- water resources - an indicator shows the state of natural waters (seas, rivers, lakes, groundwater, etc.), the quality of drinking water in the regions. This indicator also shows the quality of treated wastewater discharged into water bodies, construction and modernization of treatment facilities, etc.;

- land resources - an indicator demonstrates the state of land resources in subjects of the Russian Federation, processes of soil degradation and reclamation, and application of environmentally friendly technologies for land use;

- specially protected natural areas - an indicator reflects the number and area of specially protected areas in a region, their condition, events related to their protection, and level of funding;

- bio-resources - an indicator reflects the state of all biological resources of a region, for example, hunting or fishing stocks, increasing or decreasing diversity, quality and quantity;

- climate - an indicator that reflects climate change in a region of the Russian Federation. This indicator also considers natural disasters associated with extreme weather conditions (typhoons, hurricanes, droughts, forest fires, floods).

Starting from 2008, the "Green Patrol" ecological rating has been done on a quarterly basis. For the analysis and selection of regions, the authors used data from spring 2019. The average environmental index is 47 (out of 100) among all regions. Regions with an index below the average were excluded from further analysis. Since one factor of consumer confidence in organic products is the environmental quality in the production area, regions with a higher environmental quality have a higher priority for the development of organic production. Thus, regions with a suitable measure on the environmental index are: Kabardino-Balkaria, Karachay-Cherkess Republic, Republic of Adygea, Jewish Autonomous Region, Tambov Region, Altai Republic, Magadan Region, The Republic of Ingushetia, Kursk region, Komi Republic, Kostroma region, Altai region, Kamchatka region, North Ossetia Alania, Tyva Republic, Chechen Republic, Belgorod region, The Republic of Dagestan, Republic of Kalmykia, Ulyanovsk region, Ryazan' Oblast', Mari El Republic, Stavropol' region, Pskov region, Sakhalin region, Chuvash Republic, Republic of Karelia, Vladimir region, Murmansk region, Penza region, Kaluga region, Kemerovo region, Chukotka, Ivanovo region, The Republic of Khakassia, Amur region, Krasnodar region, Perm' region, Astrakhan' region, Tver' region, Republic of Sakha (Yakutia). 
The task of the second stage of the study is to differentiate regions according to two parameters: area of unutilized agricultural land and unemployment rate in regional rural territories. Regions that are the part of the relatively clean group with an average annual environmental index above the average were then divided into four groups according to two parameters: the area of unutilized agricultural land, and the level of unemployment in the rural terrain.

A production process without mineral fertilizers is one requirement for organic agriculture. As noted, Russia has significant areas of unused agricultural land that are an important reserve for organic farming. According to the Russian agricultural census in 2016, 17628.8 thousand ha of agricultural land are not used for intended purposes - this is $12 \%$ of all agricultural land in the country (142659.7 thousand ha). Agricultural land can be declared unused after it has been unutilized for three years. We can use these data to analyze the potential for developing organic agriculture. However, despite the improvement of soil quality due to the absence of mineral fertilizer, the physical properties of unutilized land deteriorate due to wind- and water-erosion, shrubs, and other weeds. Every year the quality of unutilized agricultural land degrades. The restoration of quality of such lands requires significant additional costs, which reduces the attractiveness of their use for organic production. To solve this problem, in 2011 a special Federal Law was adopted that makes it possible to withdraw land in case of its improper use and return it to agricultural circulation. Consistent implementation of the norms of this law will allow transferring these lands to more efficient owners, perhaps, for the purposes of organic production.

According to the statistical data, we divide all regions into two groups: regions with more than average value of unutilized agricultural land and regions with less than one (Table 1). The average value of unutilized agricultural land is 160 thousand ha (among the abovementioned regions).

Table 1. Area of unutilized agricultural land in Russian regions, 2016

\begin{tabular}{|c|l|}
\hline \multicolumn{1}{|c|}{$\begin{array}{c}\text { Area of unutilized } \\
\text { agricultural land }\end{array}$} & \multicolumn{1}{c|}{ Names of regions } \\
\hline More than 160 thousand ha & $\begin{array}{l}\text { Astrakhan' region, Republic of Kalmykia, The Republic of Dagestan, } \\
\text { Chechen Republic, Tver' region, Penza region, Altai Territory, Pskov } \\
\text { region, Amur region, Ulyanovsk region, Vladimir region, Perm' Territory, } \\
\text { Mari El Republic, Ryazan' region }\end{array}$ \\
\hline Less than 160 thousand ha & $\begin{array}{l}\text { Stavropol' region, Jewish Autonomous Region, Kemerovo region, Tambov } \\
\text { Region, Krasnodar region, Kaluga region, Altai Republic, Kursk region, } \\
\text { Kostroma region, Ivanovo region, Belgorod region, The Republic of Sakha } \\
\text { (Yakutia), Republic of Khakassia, Republic of Adygea, Tyva Republic, } \\
\text { Republic of North Ossetia-Alania, Chuvash Republic, Karachay-Cherkess } \\
\text { Republic, Republic of Karelia, Sakhalin region, Republic of Ingushetia, } \\
\text { Komi Republic, Kamchatka Territory, Kabardino-Balkaria, Murmansk } \\
\text { region, Magadan Region, Chukotka Autonomous Region }\end{array}$ \\
\hline
\end{tabular}

B a sed o n: The Russian Federal Department of Statistics. URL: http://www.gks.ru/free_doc/new_site/business/ sx/vsxp2014/vsxp2016.html (accessed: 26.02.2020).

For the third stage we consider social factors. Social factors of development of organic agriculture are bounded with the unemployment rate of rural people. Organic technolo- 
gies are known to be more labor-intensive; therefore, one cannot ignore the availability of labor in analyzed regions.

Organic agriculture impacts social sphere of rural territories in different ways. We list several factors.

1. The development of entrepreneurial activity through diffusion of new organic technologies. Products are to be produced in accordance with organic requirements. Not only new scientific knowledge in fields of botany, biology, and agronomy is necessary, but so are new organic technologies, including organic innovations. As a result, organic farms tend to be more innovative than conventional farms.

2. The employment of unskilled workers. Currently, the serious social problems of the rural population are associated with the migration of young people to cities due to a high level of unemployment. The crisis period in agriculture that lasted for several years has led to the degradation of the workforce. Organic farms can provide workplaces for people in a plant producing, in dairy farms, and in the harvesting of wild plants. It must be noted that harvesting of wild plants is widely used both in organic agriculture in Russia and in conventional agriculture.

3. Development of a natural way of life in rural territories. The popularization of natural rural culture in eco-settlements can save Russian national culture. Organic farming diffuses the way of production without chemical fertilizers and other chemical resources. Thus, it goes back to traditional for Russian people natural technologies of food production.

The definition of promising regions for the development of organic production also assumes an analysis of the level of unemployment of rural population in regions. The state of employment in agriculture and unemployment of rural population is shown in Table 2. In Russia, this is equal to $8 \%$ in 2017 . We grouped regions into two groups in accordance to the level of unemployment.

Table 2. Groups of Russian regions according to the unemployment rate of rural population, 2017

\begin{tabular}{|l|l|l|}
\hline No & $\begin{array}{l}\text { Unemployment rate in rural } \\
\text { territory of regions }\end{array}$ & \multicolumn{1}{c|}{ Name of regions } \\
\hline 1 & $\begin{array}{l}\text { More than 8\% (average in } \\
\text { Russia) }\end{array}$ & $\begin{array}{l}\text { Republic of Ingushetia, Tyva Republic, Karachay-Cherkess Republic, } \\
\text { Republic of North Ossetia-Alania, Republic of Dagestan, Republic } \\
\text { of Adygea, Chechen Republic, Altai Republic, Altai Territory, } \\
\text { Kabardino-Balkaria Republic, Jewish Autonomous region, Republic } \\
\text { of Kalmykia, Republic of Karelia, Astrakhan' region, Pskov region, } \\
\text { Komi Republic, Perm' Territory, Kemerovo region, Kamchatka } \\
\text { Territory, Murmansk region, The Republic of Sakha (Yakutia), Amur } \\
\text { region, Ulyanovsk region }\end{array}$ \\
\hline 2 & $\begin{array}{l}\text { Less than 8\% (average in } \\
\text { Russia) }\end{array}$ & $\begin{array}{l}\text { Ryazan' region, Stavropol' region, Kostroma region, Vladimir } \\
\text { region, Penza region, Sakhalin region, Mari El Republic, Republic } \\
\text { of Khakassia, Tver' region, Kursk region, Ivanovo region, Tambov } \\
\text { region, Kaluga region, Magadan region, Chuvash Republic, Belgorod } \\
\text { region, Chukotka Autonomous region, Krasnodar Territory }\end{array}$ \\
\hline
\end{tabular}

B a se d on: The Russian Federal Department of Statistics. URL: http://www.gks.ru (accessed: 12.01.2020).

For the analysis of the unemployment rate, data for the year 2015 were taken, which are now the most relevant. Our use of data on the state of the environment, unutilized ag- 
ricultural lands, and level of unemployment in Russian regions for different time periods is justified, along with the availability of data, their weak variability in several positions. The desire of the authors to conduct research based on the most relevant data is also determined by the intention to use the obtained results to justify the strategic trends in the development of organic agriculture in Russia.

Integration of ecological, economical, and social parameters of these regions allows us to identify regions where the development of organic agriculture is of the highest priority. We distinguished four groups of regions that comprise in descending order regarding organic agriculture development (Figure 2).

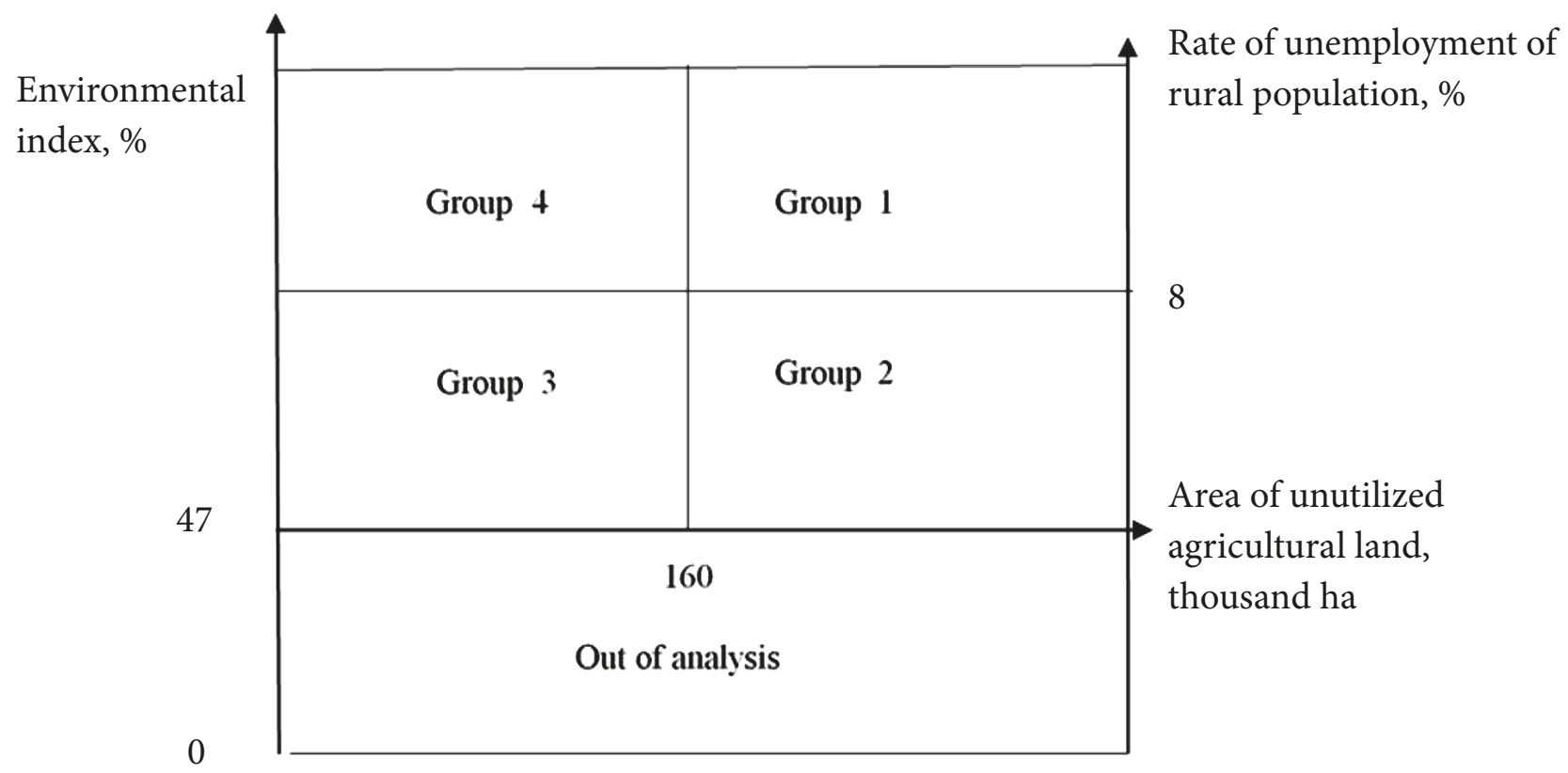

Fig. 2. Grouping of Russian regions according to environmental, productive and social parameters

Group 1 combines the following regions: Republic of Dagestan, Chechen Republic, Altai region. Jewish Autonomous Region, Republic of Kalmykia, Astrakhan' region, Pskov region, Perm' region, Amur region, Ulyanovsk region. The geographical spread of these regions is shown on the Figure 3.

As is shown in Figure 2, regions of group 1 are characterized by a high level of rural unemployment and large areas of unutilized agricultural land (more than 160 thousand ha). They have the maximum potential for the development of organic agriculture, which makes it possible to produce products in large volumes.

Group 3 has an opposite state, with minimal potential for development of organic agriculture among chosen regions. This group consist of following regions: Republic of Ingushetia, Tyva Republic, Republic of North Ossetia-Alania, Karachay-Cherkess Republic, Republic of Adygea, Altai Republic, Kabardino-Balkaria, Republic of Karelia, Komi Republic, Kemerovo region, Kamchatka Territory, The Republic of Sakha (Yakutia), Murmansk region. Their geographical area is shown in Figure 4.

Regions in group 2 and group 4 are in between groups 1 and 3. Group 2 has a lower level of rural unemployment and large areas of unutilized agricultural land. Group 3, in contrast, has got a high level of rural unemployment and not a large area of unutilized agricultural land. As a result, regions in these groups have relatively low potential for or- 


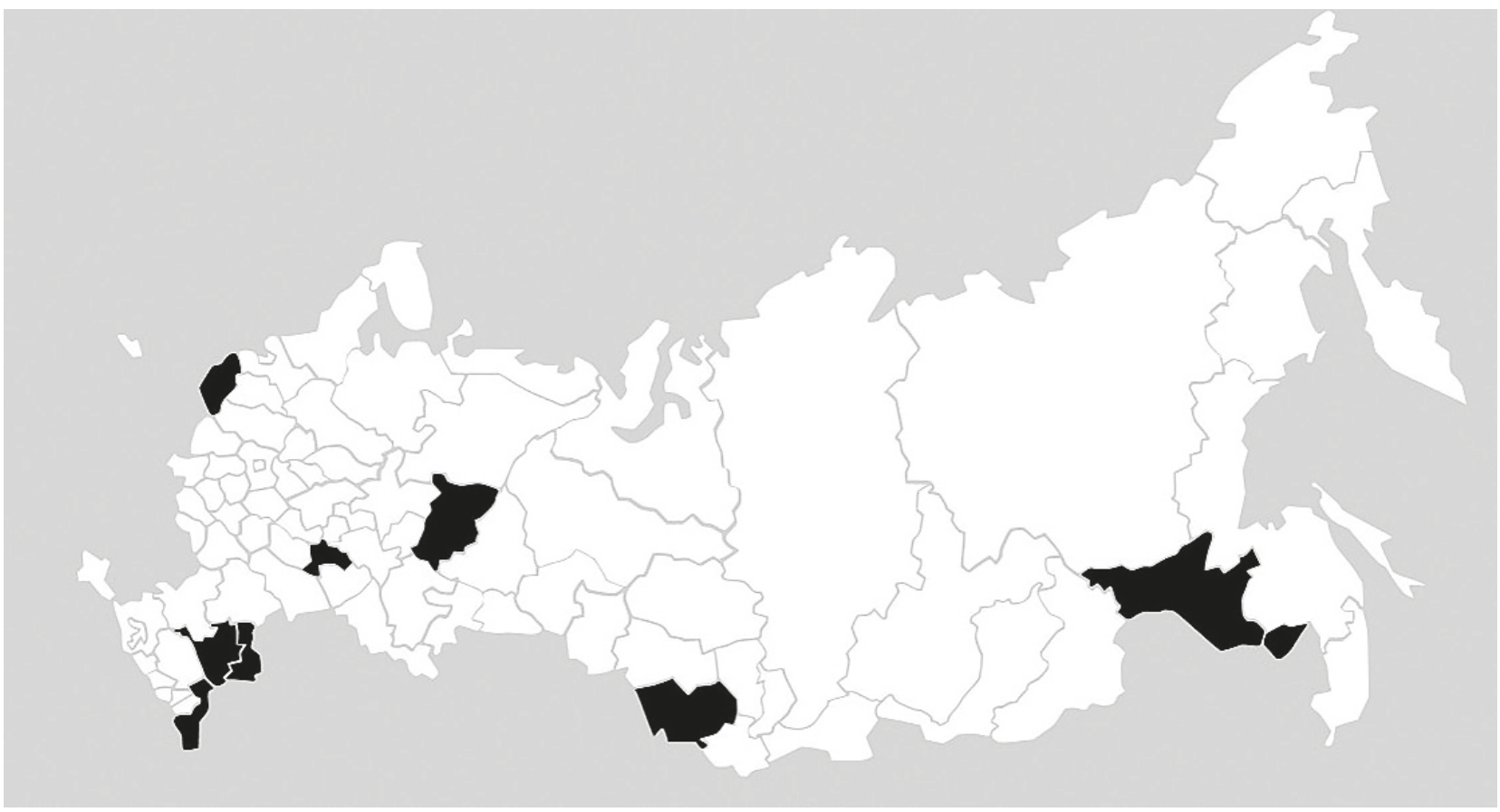

Fig. 3. Russian regions with large area of unutilized agricultural land and the rate of unemployment of rural population above average in Russia (group 1 - highlighted in black).

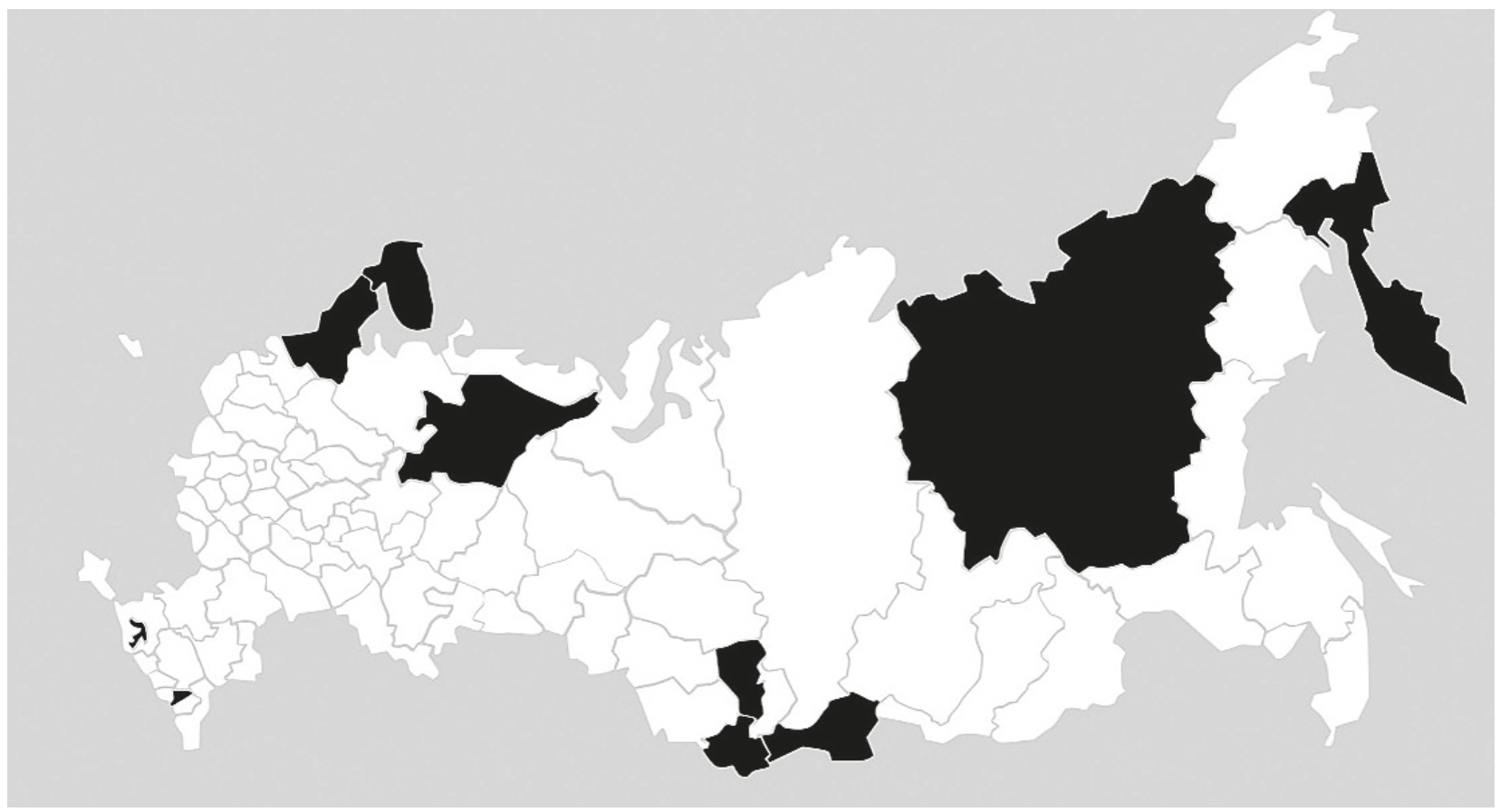

Fig. 4. Russian regions with area of unutilized agricultural land lower than average in Russia and the rate of unemployment of rural population lower than average in Russia (group 3 - highlighted in black)

ganic farming. Regions from group 2 and group 4 include the following regions: Ryazan' region, Stavropol' region, Penza region, Vladimir region, Mari El Republic, Tver' region, Kostroma region, Sakhalin region, Krasnodar region, The Republic of Khakassia, Kursk region, Tambov region, Ivanovo region, Kaluga region, Chuvash Republic, Magadan region, Belgorod region, Chukotka Autonomous region (Figure 5). In a productive aspect, these regions have the medium potential for the development of organic production. 


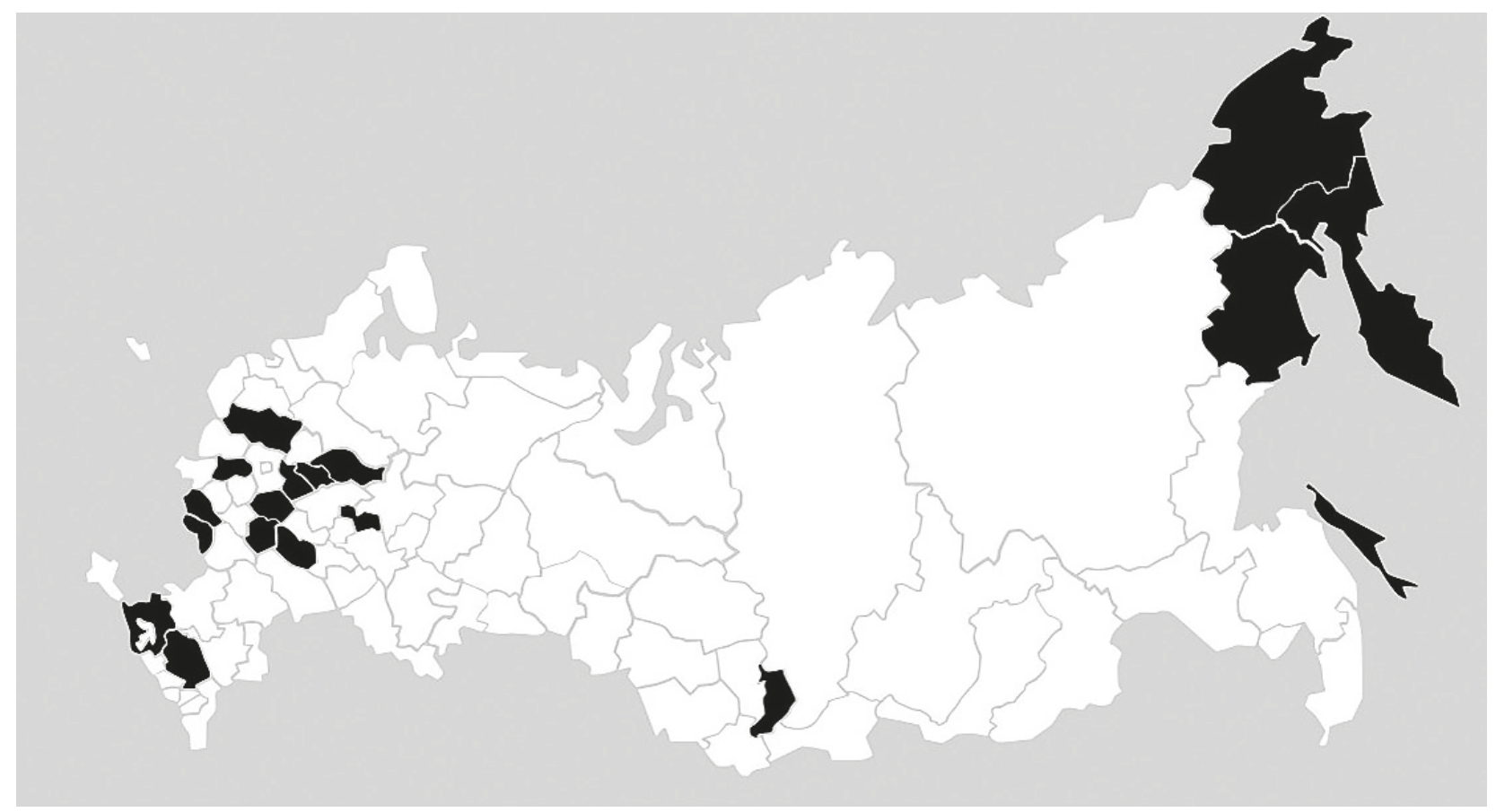

Fig. 5. Russian regions with a medium potential for development of organic agriculture (groups 2 and 4 - highlighted in black)

To reveal product specialization of each group of Russian regions it is necessary to clarify product niches of organic agriculture. Product differentiation with regional definition is useful for further analysis for developing strategies for organic agriculture. In accordance with types of products and their role in the supply chain, the authors identified the following niches: 1) organic raw materials for further processing in the food industry and related industries; 2) fresh organic products of short shelf life without processing; and 3) wild collection.

The niche of organic raw materials for further processing needs much agricultural area and labor. This niche includes organic raw materials for food, chemical and light industries, and certainly for agriculture. The supply chain in this niche can be long because the shelf life of these goods is not short. The location of production does not matter for the end consumer, just an ecological state of region of production. Since in this niche a processor plays a key role in the supply chain, the volume of production is restricted only by a processor's capacities and is not limited by the level of effective demand. Moreover, organic raw materials can be delivered for export like conventional ones. The products of this niche can be distinguished by the following categories: organic products for further processing in food industry (berries, fruits, vegetables, meat and milk for conservation), cereals for processing and packaging (wheat, rye, rice, beans), medicinal plants for the chemical industry (medical and cosmetic products from organic raw materials), organic animal feeds for organic farms, and organic textile material.

The niche of organic food with a short shelf life needs production processes oriented to maintaining freshness. The production of fresh food for end consumers requires short supply chain. These are meat and dairy products, fresh vegetables and fruits, berries, and mushrooms. Requirements for this organic food suggest the absence of chemical preservatives, improvers, and dyes. A basic reason for buying organic food is a desire to consume healthy environmentally friendly food. Children, as well as adults with specific diseases, 
are also included in the consumer group for which a healthy diet is required. The next reason to be certified is trust in the quality of products which can be provided by a direct production process control, as well as the location of the production in an environmentally friendly region.

The third niche is "Organic wild collection". This group of products is allocated to a separate niche, as a production process is limited to harvesting wild plants, their packaging, and transportation. Currently, up to $8 \%$ of all areas certified in accordance with organic requirements in Russia is set aside for wild collection. We see good prospects for the development of this niche, since large areas of the country are covered with environmentally friendly forests. This, in turn, requires a large labor force. Large areas of unutilized agricultural land are not required, therefore, for the implementation of this niche of organic agriculture, the regions of group № 1 are more suitable.

\section{The differentiation of regional strategies for organic agriculture: Results and discussion}

From out study we can confirm the assumption that strategies for developing organic agriculture in Russia should consider the geographical, economic, and social parameters of regions. Distinguishing four groups of regions allows us to focus development strategies on individual product niches: food with short shelf life and minimum processing, organic raw materials for food and other related industries, and harvesting of organic wild plants and fruits. Such differentiation will enable not only to fully adapt supply chains to the capabilities of its members but also to solve several environmental and social problems.

Large-scale production of organic raw materials is possible. The main limiting factor is processor capacity. At the same time, this niche has great export potential, as the global market for organic products is constantly growing. Russia can occupy a certain market share by selling organic raw materials. Large areas of unutilized agricultural land, which provide a considerable reserve for development of agriculture in Russia as a whole, can be used for organic farming. In this context, with an increase of production in agriculture the costs of reclamation of soil can be considered unavoidable. By using a large amount of manual labor in this product niche, unemployment in rural areas can be reduced.

According to specific features of this niche, regions from group 1 (Republic of Dagestan, Chechen Republic, Altai region. Jewish Autonomous Region, Republic of Kalmykia, Astrakhan' region, Pskov region, Perm' region, Amur region, Ulyanovsk region) are more suitable. As we can see on Figure 3, many regions are near the national border, so the development of exports of organic raw materials can be organized with a minimization of transport costs.

Harvesting wild plants and fruits is a perspective niche, because most territory in the Russian Federation is covered with environmentally friendly forests. The production process consists of harvesting ripened fruits and plants and selling them to further processors. The export potential for organic wild plants is quite high, especially in the Asian region. For this niche, large agricultural areas are not required, as major production areas are in a forest zones. Because of the seasonal involvement of the population for harvesting, unemployment in respective regions may be partly solved. Carrying out regional differentiation in the development of organic agriculture makes it possible to specify organizational activities both from state and business points of view. Regions from group 3 (Ryazan' region, 


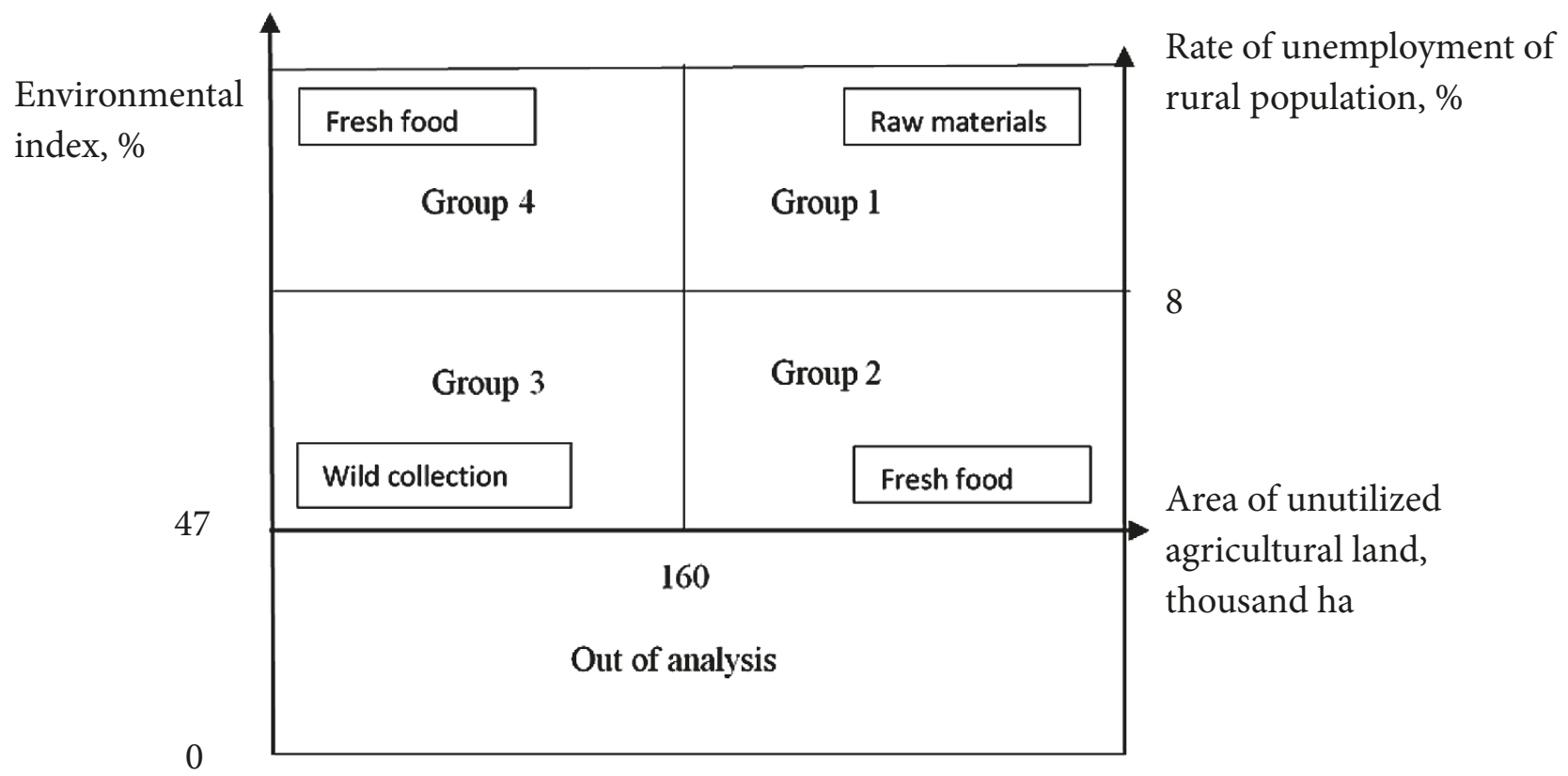

Fig. 6. Product niches of organic agriculture according to regional differentiation

Stavropol' region, Penza region, Vladimir region, Mari El Republic, Tver' region, Kostroma region, Sakhalin region, Krasnodar region, The Republic of Khakassia, Kursk region, Tambov region, Ivanovo region, Kaluga region, Chuvash Republic, Magadan region, Belgorod region, Chukotka Autonomous Region) could provide organic wild collection especially most of them are covered by forests.

Development of organic food production with minimal processing and short shelf life is possible in the form of organizing small organic farms because of requirements to be close to consumers. This form of organization allows minimization or risks associated with production processes and changes in consumer preferences, as well as financial risks due to small production volumes. At the same time, it can provide an impetus to developing innovative entrepreneurship in rural areas through the exchange of positive experience not only in the organic production sector, but also in agriculture. In addition, small organic farms carry out the function of preserving and transferring traditional Russian rural culture using old recipes and methods of farming in production processes. Regions from group 2 and group 4 could be more suitable for development of this product niche. The significant part of these regions is in European part of Russia which is characterized by high effective demand on organic food. Moreover, institutionally European part of Russia is more developed for organic market.

The scheme for producing niches of organic agriculture, given regional differentiation, is shown on the Figure 6.

\section{Summary and outlook}

The analysis confirmed the importance of agriculture, using the case of Russia, to achieve objectives of the Paris climate accords and the formation of a stable low-carbon economy oriented to the expanded use of alternative energy and the integrated introduction of technological, organizational, institutional, and marketing innovations. For the agricultural sector, an important role in achieving these goals is the dissemination of prin- 
ciples of organic agriculture, which must be applied in a balanced manner, considering the fulfilment of this sector's entire range of economic, social, and environmental functions. The authors based their research on the modern model of organic farming, "organic farming 3.0", which is characterized by a shift in emphasis from a purely agricultural perspective to organic production as an agri-food system. An important role in forming the methodological basis of the study was also given to the "European Initiative for Sustainable Development in Agriculture" with its goal to merge the advantages of traditional industrial methods with the requirements of the organic agriculture. The answers to current climate and environmental challenges should be the zone of responsibility not only for the model of organic production but also be consistently addressed within the traditional industrial sector of the Russian agrarian economy.

A successful implementation of the strategy for sustainable development of organic production, however, is less beneficial without the targeted use of digital technologies. The main areas of their application and effects obtained include the following:

- cloud computing and large database technologies, which contribute to the development of precision farming as a key component of the fourth wave of modern, digital, revolution; precision agriculture means applying the precise and correct amount of different resources (water, fertilizer, pesticides etc.) at the correct time to increase crop productivity, maximize its yield and to improve overall environmental performance;

- use of industrial Internet and high-resolution satellite data, which not only can organize online monitoring of the quality of the interconnected technological chains of organic production, but also can contributes to the transparency of business processes, and, as a result, can maintain high quality and consumer confidence in organic products;

- computerization and robotization, which have significant potential in reducing the need for workers engaged in manual operations and the shortage of highly qualified personnel in rural areas;

- active development of digital platforms that facilitate the promotion of organic food by organizing networking between producers and consumers; such platforms reduce the number of intermediaries, combine manufacturers from different regions with minimal transaction costs, help realize economies of scale and reduce the gap between the supply and the demand for organic products in the regional context, etc.

The strategic development of agriculture should aim for its intensive development to meet the growing population's food needs and to increase the country's export earnings with targeted environmental measures. These measures should be coordinated with the tasks of the Paris Climate Agreement in 2015 to prevent irreversible climate change and environmental degradation. Of importance in this context are agriculture-servicing branches, including the production of mineral fertilizers, which are among the priority in terms of reducing greenhouse gas emissions.

The article focused on the model of organic agriculture, which plays a special role in reducing the risk of irreversible climate change and the risks of environmental pollution. For its accelerated development it is necessary, first, to form adequate institutional conditions that support this rapidly developing segment of agricultural production. The prepa- 
ration of a package of regulatory documents that ensure the implementation of the Federal Law "On the Production of Organic Products" (No. 280-FL) has in modern conditions the greatest relevance. Second, in determining the strategic priorities for the development of organic agriculture, it is necessary to consider the diversity of natural and climatic conditions prevailing in different regions of the country, as well as the availability of appropriate production and socio-economic resources. And third, to achieve the goals of sustainable development, it is recommended to fully realize the potential of digital technologies.

Considering the three dimensions of sustainable development, the paper justified three groups of indicators, namely ecological, economic, and social, that form the basis for classifying regions of Russia to identify those that have the most favorable conditions for developing organic agriculture. Further, the authors suggested possible grocery niches for the development of organic agriculture and the supply chains corresponding to these niches, which can find effective application in the groups of regions that were defined in the article. The recommendations resulting from the analysis carried out in the article may be of interest both for business and for regulating bodies in charge of developing strategies for the organic agriculture in Russian regions.

This study also identifies several issues for analysis in subsequent publications. For sustainable development of organic agriculture, it is essential to balance supply and demand for organic products. Considering the importance of ensuring this balance, our focus was on the supply side. The formation of stable demand for organic products requires further study. These include ensuring the availability of organic food, including through effective social policies and reducing unjustified differentiation in incomes of various segments of the Russian population. The organic food segment also needs special marketing research to increase its export potential.

The next issue regarding the development of organic agriculture is to predict dynamics of GHG emissions. It cannot be said that production of organic products has no negative impact on the environment. Data on the environmental burden of organic farms in comparison with traditional farms is provided in several papers [Williams, Audsley, Sandars, 2006; Schulze, 2014]. There is an ambiguous impact of organic agriculture on GHG emissions. In this regard, it is of interest to simulate these emissions while implementing a strategy of agricultural development, including the organic sector.

There is a significant ongoing discussion in the Russian scientific literature on the need for state support for organic agriculture. Critics are concerned about the inability of this sector to solve the food security problem and provide the population with domestically produced environmentally friendly food. Their position is explained by the lower productiveness of organic agriculture in comparison with traditional. In terms of solving environmental problems, organic agriculture becomes not only a supplier of more environmentally friendly food, but also initiates a significant number of innovations related to the development of environmentally friendly technologies.

\section{References}

Aganbegyan A.G., Porfiryev B.N. (2015) Substitution of food imports and the development of a "green" agroeconomy as strategic responses to anti-Russian sectoral sanctions. Economy of agricultural and processing enterprises, vol. 2, pp. 16-27. (In Russian)

Altieri M., Nicholls C., Henao A., Lana M. (2015) Agroecology and the design of climate change-resilient farming systems. Agronomy for Sustainable Development, vol. 35, pp. 869-890. 
Altukhov A., Nechaev V., Porfiriev B. (2013) “Green” Agroeconomics: monography. Moscow, RGAU MSHA Publ. 247 p. (In Russian)

Arbenz M., Gould D., Stopes C. (2017) ORGANIC 3.0 - the vision of the global organic movement and the need for scientific support. Organic Agriculture, vol.7, no.3, pp.199-207. https://doi. org/10.1007/s13165-017-0177-7

Arkhipova V.A., Kulagina A.G. (2018) Formation and development of the Russian market of products of organic agriculture. Economics and Entrepreneurship, vol.2, iss.91, pp.738-742. (In Russian)

Atănăsoaie G. (2011) Distribution channels on the organic foods market. Journal of Horticulture, Forestry and Biotechnology, vol. 15, iss. 3, pp. 19-25.

Avilova A. (2016) What are perspectives of organic agriculture in Russia? Vestnik of Russian Academy of Sciences, vol. 86, iss. 3, pp. 237-243. (In Russian)

Chukhlantsev A. Yu. (2019) Organic Products. Basic requirements. Sanepidcontrol. Occupational Safety and Health, vol. 2 (March-April), pp. 116-126. (In Russian)

Danshin A.I. (2018) Export potential of the agro-industrial complex of Siberia and the Far East. Moscow University Bulletin. Ser. 5. Geography, vol. 4, pp. 101-108. (In Russian)

Davidson E. A. (2009) The contribution of manure and fertilizer nitrogen to atmospheric nitrous oxide since 1860. Nature Geoscience, vol. 2 (September), pp. 659-662.

De Moraes S., Sá J.C., Lal R., Cerri C.C, Lorenz K., Hungria M., de Faccio Carvalho P.C. (2017) Lowcarbon agriculture in South America to mitigate global climate change and advance food security. Environment International, vol. 98, pp. 102-112.

Einfalt D., Kazda M. (2016) Characterisation of biogas plants on organic farms and potentials for improvement. Organic Agriculture, vol. 6, pp. 243-254.

Grigorian B. R., Kulagina V. I., Sungatullina L. M. (2016) Problems of agrotourism development on the basis of organic farms in republic Tatarstan. Agroecology, vol.2, pp. 19-21. (In Russian)

Honkanen P., Frewer L. (2009) Russian consumers' motives for food choice. Appetite, vol. 52, iss. 3, pp. 363371. https://doi.org/10.1016/j.appet.2008.11.009

Knoll F. J., Czymmek V. (2018) The German Vision of Industry 4.0 Applied in Organic Farming. In: Hussmann St. (ed.) Automation in Agriculture - Securing Food Supplies for Future Generations, pp. 17-34.

Komarova O. V., Beresneva R.I. (2019) Development of the market of organic agriculture in Russian Federation. Questions of science: innovation, technology and technology, vol. 1, pp. 89-94. (In Russian)

Klimova N. V. (2017) The Policy of Accelerated Agricultural and Food Import Substitution in Russia. Economics of Agriculture of Russia, vol. 1, pp. 10-14. (In Russian)

Kravchenko A., Stetsyuk V., Kuripko A. (2019) Organic Food Market: Prospects of Development in Russia. Economy of agricultural and processing enterprises, vol.4, pp. 54-65. (In Russian)

Labykin A. (2019) Transnational companies believed in the Russian "organic". Expert, vol. 11 (March 1117), pp. 23-25. (In Russian)

Long D. H., Lee F. N., Tebeest D. O. (2011) Effect of nitrogen fertilization on disease progress of rice blast on susceptible and resistant cultivars. Phytopathology, vol. 101, pp. 696-709.

Nesterenko N., Artemova D. (2018) Prospects of development of sustainable supply chains of organic food in Russia. Economics of Agriculture in Russia, vol. 7, pp.2-16. https://doi:10.32651/2070-0288-2018-72-14 (In Russian)

Nesterenko N. Yu., Pakhomova N. V. (2016) Organic Agriculture in Russia: The Conditions of Transition to the Sustainable Development Trajectory. Economics of Agriculture of Russia, vol. 12, pp. 34-41. https:// doi:10.32651/2070-0288-2016-12-34-41 (In Russian)

Nesterenko N., Shagalkina M. (2019) Comparative characteristics of the organic food market in Russia and Germany. IOP Conference Series: Earth and Environmental Science on May 01, 2019, vol.247, pp. 1-8. doi.org/10.1088/1755-1315/274/1/012059

Norse D. (2012) Low carbon agriculture: Objectives and Policy Pathways. Environmental Development, vol. 1, pp. 25-39.

Pakhomova N. V., Nesterenko N. Y., Richter K. K. (2017). Organic Agriculture in Russia: ways to ensure sustainable development in the conditions of global challenges. Economic performance, environmental innovation, climatic and energetic policy. Book of proceedings, SPb.: Skifia-Print. pp. 200-215. (In Russian)

Pertseva E. (2019) Organic Growth: Russia will create a "green" brand. Izvestiya, February 21. URL: https://iz.ru/ 848104/evgeniia-pertceva/organicheskii-rost-v-rossii-sozdadut-zelenyi-brend (accessed: 22.02.2020). (In Russian) 
Porfiryev B. N. (2015) Development of a "green agroeconomy" in Russia - a long-term response to sanctions and the strategic direction of modernization of the domestic agro-industrial complex. Russian Economic Journal, vol. 1, pp. 110-116. (In Russian)

Prospects for the development of organic agriculture in Russia (2019) SBS Consulting research. March 2019. URL: https://www.sbs-consulting.ru/upload/Organic_agriculture_perspectives_in_Russia_ Mar2019\%20.pdf (accessed: 18.01.2020). (In Russian)

Popova K., Frewer L. J., Jonge J. D., Fischer A., Kleef E. V. (2010) Consumer evaluations of food risk management in Russia. British Food Journal, vol. 112, iss.9, pp. 934-948.

Rahmann G., Reza Ardakani M., Bàrberi P. et al. (2017) Organic Agriculture 3.0 is innovation with research. Organic Agriculture, vol. 7, pp. 169-197. https://doi.org/10.1007/s13165-016-0171-5

Richter K. K., Pakhomova N. V. (2018) Digital economics as a 21 c. innovation: challenges and chances for sustainable development. The problems of Modern Economy, vol. 2, iss. 66, pp. 22-31. (In Russian)

Schulze E., Pakhomova N., Nesterenko N., Krylova Y., Richter K. (2015) Traditional and Organic Agriculture: Analysis of Comparative Efficiency from the Position of the Sustainable Development Concept. St Petersburg University Journal of Economic Studies, iss. 4, pp. 4-39. (In Russian)

Schulze E. (2014) Nachhaltigkeit, ökologischer und konventioneller Landbau. Eine Erwiderung auf die Denkschrift "Leitbild Schweiz oder Kasachstan?" von Michael Beleites. Veröffentlichungen der Leipziger Ökonomischen Societät, iss. $22.47 \mathrm{~s}$.

Schulz F. (2012) Vergleich ökologischer Betriebssysteme mit und ohne Viehhaltung bei unterschiedlicher Intensität der Grundbodenbearbeitung. Effekte auf Flächenproduktivität, Nachhaltigkeit und Umweltverträglichkeit. Berlin. Giessener Schriften zum Ökologischen Landbau. Bd. 5. 227 s.

Shcherbakova A.S. (2017) Assessment of the development of the market for the production of organic agricultural products in Russia. North and the Market: the formation of the economic order, vol. 1, pp.92102. (In Russian)

Skvortsov E. A., Skvortsova E. G., Sandu I. S., Iovlev G. A. (2018) Transition of Agriculture to Digital, Intellectual and Robotics Technologies. Ekonomika regiona, vol. 14, iss. 3, pp. 1014-1028. (In Russian)

Smith P., Martino D., Cai Z., Gwary D., Janzen H., Kumar P., McCarl B., Ogle S., O’Mara F., Rice C., Scholes B., Sirotenko O. (2007) Agriculture. In Climate Change 2007: Mitigation. In: Metz, B., Davidson, O. R., Bosch, P. R., Dave, R., Meyer, L. A. (Eds.). Contribution of Working Group III to the Fourth Assessment Report of the Intergovernmental Panel on Climate Change. Cambridge, NY, Cambridge University Press.

Strotdrees S., Strotdrees L., Braun S., Rahmann G. (2011) Ökolandbau 3.0? Landbauforsch SH. 354, ss. 5-8. Willer H., Lernoud J. (Eds.) (2019) The World of Organic Agriculture. Statistics and Emerging Trends 2017. Bonn, FiBL, Frick and IFOAM - Organics International. Version 1.3 of February 20. URL: http:// www.organic-world.net/yearbook/yearbook-2019.html (accessed: 07.02.2020).

Williams A., Audsley E., Sandars D. (2006) Determining the environmental burdens and resource use in the production of agricultural and horticultural commodities. Main Report Defra Research Project ISO205. Bedford, Cranfield University and Defra Publ.

Received: 20.07.2019

Accepted: 20.02 .2020

Authors' information:

Natalia Yu. Nesterenko - PhD in Economics; n.nesterenko@spbu.ru

Nadezda V.Pakhomova - Dr. Sci. in Economics, Professor; n.pahomova@spbu.ru

Kurt Knut Richter - PhD in Economics, Dr. Sci. in Physics and Mathematics, Professor;

k.rihter@spbu.ru 
Устойчивое развитие органического сельского хозяйства: стратегии России и ее регионов в контексте применения технологий цифровой экономики

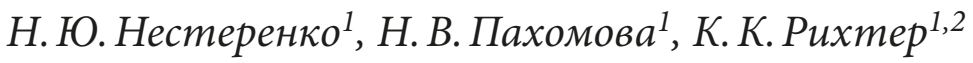 \\ ${ }^{1}$ Санкт-Петербургский государственный университет, \\ Российская Федерация, 199034, Санкт-Петербург, Университетская наб., 7-9 \\ 2 Европейский университет Виадрина, \\ Германия, 15230, Франкфурт (Одер), Гросе Шаррнштрассе, 59
}

Для цитирования: Nesterenko N. Yu., Pakhomova N. V., Richter K. K. (2020). Sustainable development of organic agriculture: Strategies of Russia and its regions in context of the application of digital economy technologies. Вестник Санкт-Петербургского университета. Экономика. Т. 36. Вып. 2. С. 217-242. https://doi.org/10.21638/spbu05.2020.203

В статье органическое сельское хозяйство анализируется с точки зрения его способности эффективно удовлетворять растущий спрос на высококачественные продукты питания, увеличивать экспортный потенциал и решать проблемы импортозамещения в стране. Специально рассматриваются экологические и климатические последствия интенсификации аграрного сектора экономики. Наряду с этим раскрывается важность технологий цифровой экономики для повышения устойчивости органического производства. К числу наиболее значимых в этом контексте относятся: облачные вычисления и большие базы данных, которые способствуют развитию точного земледелия; постоянный онлайн-мониторинг качества различных этапов технологических цепочек; автоматизация и роботизация как средство снижения возрастающего спроса на трудовые ресурсы для органического производства, в особенности в секторах с преобладанием ручного труда. Следуя рекомендациям концепции «Органическое сельское хозяйство 3.0», авторы изучают соответствующие экологические, экономические, социальные и институциональные факторы для разработки комплексных стратегий развития сельского хозяйства России и ее регионов. В статье применяется специальный экологический индекс, позволяющий выделить экологически чистые регионы, которые соответствуют требованиям органического производства. Экономический индекс предложено формировать с учетом оценки потенциала неиспользуемых сельскохозяйственных земель, годных для органического земледелия. В качестве социального индикатора используется показатель доли безработного населения трудоспособного возраста в сельской местности. На базе указанных индикаторов сформированы четыре группы регионов с различными условиями развития органического сельского хозяйства. С учетом наличия у регионов страны различных потенциалов для развития органического производства, а также принимая во внимание внешний институциональный контекст, авторы определяют региональные конкурентные стратегии и соответствующие им продуктовые ниши. В исследовании также приводятся рекомендации для российской аграрной и экологической политики, призванной полнее поддерживать эффективное развитие органического производства.

Ключевые слова: устойчивое развитие, технологии цифровой экономики, органическое сельское хозяйство 3.0, экспортный потенциал, спрос и предложение на органическое продовольствие, региональные приоритеты, местные цепочки поставок продовольствия.

Статья поступила в редакцию: 20.07.2019

Статья рекомендована в печать: 20.02.2020

Контактная информация:

Нестеренко Наталья Юрьевна - канд. экон наук; n.nesterenko@spbu.ru Пахомова Надежда Викторовна - д-р экон. наук, проф.; n.pahomova@spbu.ru Рuхтер Kypm Кнут - д-р физ.-мат. наук, канд. экон. наук, проф.; k.rihter@spbu.ru 